Transverse median nervure in front wings interstitial or uniting with the median vein before the origin of the basal nervure ......... 6 .

5. Hind margin of pronotum arcuate; antennæ rather thick; front tarsi with a comb; claws in $q$ with a tooth beneath, in of cleft; second cubital cell receiving one recurrent nervure, the second recurrent joining the cubitus beyond the second transverse cubitus.................. (3) Actenopoda, Ashm., g. n.

(Type A. Rileyi, Ashm., MS.)

6. Front tarsi combed; claws cleft, without or, at most, with only a

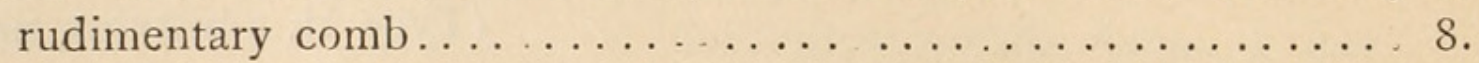

Front tarsi not combed; claws with a tooth and combed.........

7. Pronotum not large, the hind margin obtusely angularly emarginate; second cubital cell triangular ........ (4) Xenaporus, Ashm., g. n.

(Type Pompilus amoenus, Klug.)

8. Front wings with two cubital cells; hind margin of the pronotum obtusely angularly emarginate......(5) Gonaporus, Ashm., g. nov.

(Type Pompilus gracilis, Klug.)

Front wings with only one cubital cell; hind margin of the pronotum arcuate................. (6) Aporinus, Ashm., g. nov.

(Kohls gr. I 7.)

NEW COCCID $Æ$ FROM THE ARGENTINE REPUBLIC AND PARAGUAY.

BY T. D. A. COCKERELL, E. LAS VEGAS, N. M.

The Coccidæ herein described were collected by Professor L. Bruner in 1897 and 1898 . I examined the collection with more than ordinary interest, as practically nothing was known of the Coccidæe of the Argentine or Paraguay. The flora of the southern part of South America resembles in many respects that of the arid region of North America, and it was therefore not wholly unexpected that this resemblance should extend to the Coccidæ. The collection is too small to show how far such a resemblance may extend, but the species of Orthezia and Lichtensia, at least, are entirely representative of North American types.

(I.) Orthezia ultima, n. sp.- $q$. Waxy lamellæ in two dorsal series, with a deep median sulcus, and the usual lateral series; the dark surface of the back is narrowly exposed between the dorsal and lateral series; anterior lameliæ of the dorsal series thick, prolonged over the head, but not greatly produced nor divergent; posterior lateral lamellæ narrow and 
about equal in length, not adherent to the ovisac. Dried $q$ very dark brown, about II $100 \mu$ long and 1200 broad. Ovisac $3 \mathrm{~mm}$. long, fluted above.

Skin densely beset with small spines. Antennæ and legs very dark brown; lighter and redder after boiling. Antennæ 8-jointed, last joint flat on one side, convex on the other, tipped with a spine. Joints measuring in $\mu$ : (I.) 60 , (2.) 60 , (3.) 84 , (4.) 45 , (5.) 48 , (6.) 60 , (7.) 57 , (8.) 102.

Hab.-Locality uncertain, but probably Ceres, Argentine Republic. On some herbaceous plant (probably Compositæ) with linear leaves. Allied to $O$. nigrocincta from New Mexico.

(2.) Asterolecanium viridulum, n. sp.- + . Scale circular, $2 \mathrm{~mm}$. diameter, yellowish green, with hardly any fringe; $q$ boiled in caustic potash turns madder red; margin with two rows of figure-of-eight glands, those of either row I 2-I $8 \mu$ apart, and one row of simple glands, the latter not different from the scattered glands of the skin. Mouth-parts large, about I $20 \mu$ diameter; labium very short, twice as broad as long.

Hab.-Tucuman, July 26, 1 897 , "on a kind of ironweed." It is close to $A$. pustulans, and, like it, lives on the stems of the plant, producing cavities. It is a larger scale than pustulans, and has not the distinct fringe of that insect.

(3.) Akermes Bruneri, n. g., n. sp.— - . Long. $5 \frac{1}{2}$, lat. $61 / 2$, alt. $5 \frac{1}{2} 2$ mm.; shape and colour, Kermes-like; globular, shiny, smooth, broader than long, very pale ochreous, faintly marbled with a darker tint, and sparsely dotted with raised black points, which are perforated in the centre; two sulci extend upwards from the anal region in the form of a V, and other sulci occur somewhat irregularly; some individuals have a dusky reticulation. Inferior aperture, long and narrow (long. 5, lat. I I/2 $\mathrm{mm}$.), broadly margined with piceous.

q. Boiled in caustic potash turns the liquid a dark yellowish brown ; skin with a microscopical polygonal reticulation, after the manner of Eulecanium; no legs or antennæ found; in the adult the anal plates are wholly obscured, the anal region being occupied by a large, very thick, dark red-brown chitinous mass, having a coarsely radiate structure; in half-grown specimens the usual two plates are easily seen. The skin presents a number of large round dark chitinous areas, such as Signoret figures for $A$. verrucosus. 
Larva of ordinary form, with a row of large figure-of-eight (double) glands on each segment; numerous smaller round glands; no spines except the marginal ones, one on each segment on each side, about i $5 \mu$ long; no greatly produced caudal tubercles; caudal bristles two, moderately long; anal ring with six long bristles. Antennæ 5 -jointed, joint 5 with very long bristles. Joints measuring in $\mu$ : (I.) 2 I, (2.) 15 , (3.) 42 , (4.) $30,(5) 42$.

Hab.-San Bernardino, Paraguay, Sept. 23, I897, on spiny plant, probably leguminous.

The genus Akermes is closely related to Lecanium, but is distinguished by its globular form, round chitinous areas in the skin, microscopical tessellation, and the characters of the larva as described. It has some resemblance to Cryptes from Australia, but it is not likely that it has the peculiar male scale of that genus.

One other species is known, Akermes verrucosus (Lecanium verrucosum, Signoret), which I had erroneously referred to Saissetia. This is from Montevideo, and is very much larger than $A$. Bruneri.

(4.) Lichtensia simillima, n. sp.- $q$. Red-brown, with a narrow white margin, varying to ochreous; ovisac white, firm, texture leathery; o with ovisac about $5 \mathrm{r} / 2 \mathrm{~mm}$. long, $2 \mathrm{I} / 2$ high.

․ Margin with strong simple spines, about $25 \mu$ long and 30 apart; skin with many tubular glands; labium small and semicircular (as in $L$. viburni); anal plates triangular, about $\mathrm{r} 80 \mu$ long, outer sides about equal, upper surface with a long finger-like process passing from near the middle backwards and inwards, the two processes nearly meeting in the middle line.

Middle leg: femur and trochanter about $270 \mu$, tibia I 80 , tarsus I 20; tarsal digitules filiform, 60 long; claw digitules slender, about 24 long. Antennæ S-jointed, with sometimes a "false joint" in the third; joints measuring in $\mu$ : (I.) ?, (2.) 45-48, (3.) 96-I05, (4.) 33-39, (5.) 48- $5 \mathrm{I}$, (6.) $36,(7) 33,.(8) .5 \mathrm{I}$.

Hab.-On some shrubby plant. The label reads, "Scale, General Acha." Closely related to L. lycii from New Mexico.

Ceroplastes. (Wax Scales.)

The female insects are to be separated by the following tables:(a.) External Characters.

Wax of the different individuals confluent, wholly surrounding the

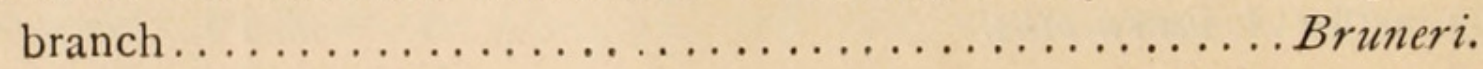


Wax not thus surrounding branch................

I. Waxy scale small, adults less than $5 \mathrm{~mm}$. long, light yellowish...scutigera.

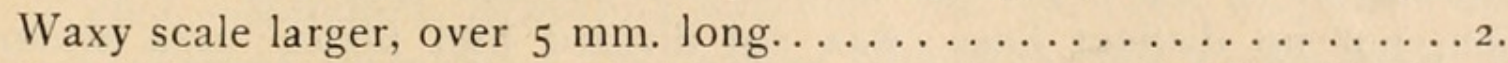

2. Wax light amber, two lines of white secretion down each side.. Mendozce. Wax creamy white, no line of white secretion down each

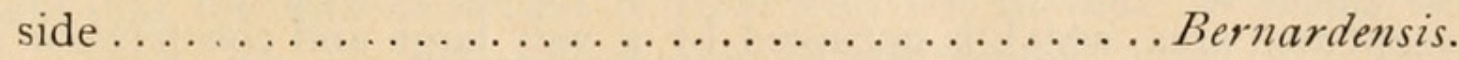

(b.) Microscopical Characters.

Strongly chitinous, with well-defined patches of perforations.. Bruneri. Less chitinous, without such patches.................

I. Small species, under $3 \mathrm{~mm}$. long, with a large, very well defined chiti-

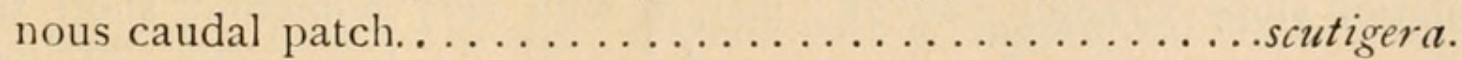

Larger, with the chitinous raudal area gradually shading into the

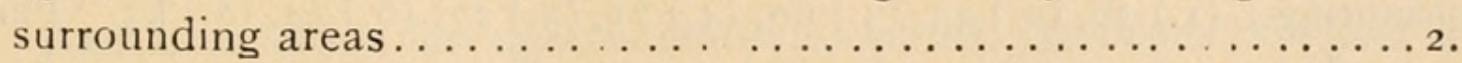

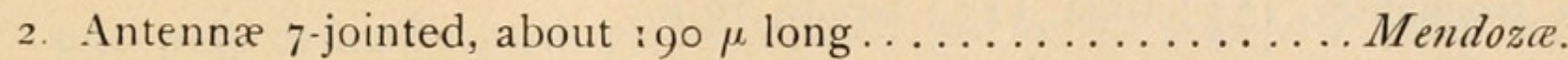
Antennæ 8-jointed, about $240 \mu$ long.......................

(5.) Ceroplastes Bruneri, n. sp. (T. D. A. \& W. P. Ckll.).

q. Wax cream-colour, surrounding twigs, the whole mass ${ }_{5} \mathrm{~mm}$. diam., the twig being $7 \mathrm{~mm}$.; dorsal nuclei shining white, sunken in deep depressions; close behind each is a small aperture through which the caudal horn is seen; the waxy mass is conspicuously flecked with snow-white secretion.

q. Dark red-brown, dorsally almost black, basally lighter and redder; subpyriform, with a truncate base; alt. $5 \frac{1}{3}$, long. 4 , lat. $5 \mathrm{~mm}$., breadth of base $21 / 2 \mathrm{~mm}$.; dorsum shiny; caudal horn short, placed at top of posterior slope and directed upwards. The horn is placed higher up than in C. candela. The insects are not separated by wax, but their adjacent sides show much chalk-white secretion, in vertical bands. Skin (dorsal and lateral surfaces) strongly chitinous throughout, orange-ferruginous by transmitted light, anal region a rich dark chestnut; large oval areas (the largest about $240 \mu$ long) full of perforations; at and near the margins the skin is strongly tuberculate, and perforate; antennæ and legs ordinary. Legs measuring in $\mu$ : femur + trochanter, about $\mathrm{I}_{35}$; tibia 105 (with a rather long hair $27 \mu$ from the end); tarsus 75 ; claw 33 , slender, nearly straight, with a slight denticle within near the base ; tarsal digitules $45 \mu$ long, rather stout.

Hab.-San Bernardino, Paraguay, Sept. 23, I897. Close to C. confluens and $C$. utilis, but especially to the S. African $C$. candela. 
(6.) Ceroplastes scutigera,n. sp.- $q$. Waxy scale about $4 \frac{1}{3} \mathrm{~mm}$. long, 3 broad, and 2 high; pale ochreous, with a lateral patch of white secretion, but no distinct lines; wax not divided into plates; area around central nucleus not darkened. q denuded of wax, about $2 \mathrm{~mm}$. long, flattish, margin tuberculate, caudal horn short. Skin semitransparent, except anal area, which is occupied by a very large and conspicuous redbrown chitinous patch, which has perfectly-defined margins, and a transverse diameter of about $900 \mu$; this patch shows a few scattered perforations, and just above the anal plates are a large number of furrows radiating from small perforations; anal plates with their long outer inferior slope strongly convex; margin with very numerous short stout spines; antennæ very pale, only about $300 \mu$ long: 7 -jointed, joints measuring: (I.) 30, (2.) 45 , (3.) 60 , (4.) 75, , (5.) 27 , (6.) $24,(7$.) 33 . Femur + trochanter, 177 ; tibia, I 23 ; tarsus, $70 \mu$.

Hab.-Ceres, Argentine Republic, June 30 , I 897 , on a shrub with small entire oval-lanceolate leaves. This may be compared with: (a.) C. minutus, which is closely allied, and has the same well-defined caudal patch; but it also has two chitinous patches on each side, containing perforations, these being quite absent in scutigera. (b.) C. speciosus has the caudal patch just as in scutigera, and lacks the lateral patches of minutus; it has spines only near the stigmata (for a distance of about 2 r० $\mu$ on each side), whereas scutigera has them all around; the antennæ of speciosus are very short, only about $\mathrm{I}_{5} \mu$ long; externally, speciosus is easily distinguished from scutigera by its dark reddish wax, with a large whitish dorsal patch. (c.) C. rotundus is smaller, with well-defined waxy plates. (d.) C.purpureus is much smaller. (e.) C. Theringi looks just like scutigera externally, but it has not the caudal patch. (f.) C. formosus has bright yellow wax.

(7.) Ceroplastes novaesi mendoze, n. subsp.-Waxy scale about $61 / 2$ $\mathrm{mm}$. long, 6 broad, 5 high; pale amber, with a decided ferruginous tint ; sides with two white lines more or less defined; wax not divided into plates, strongly nodulose.

. Denuded of wax lively ferruginous, convex, about $5 \mathrm{~mm}$. long, 4 broad, $3 \frac{1}{2}$ high; dorsum rounded, without prominences; caudal horn short, directed upwards, from hind margin to tip of caudal horn is about $21 / 2 \mathrm{~mm}$. Skin not very strongly chitinized, except around anal area; diameter of mouth-parts about I $35 \mu$; antennæ about r80-г $95 \mu$ long, joints measuring: (I.) 24, (2.) 33 , (3.) 24, (4.) 36 , (5.) I 8 , (6.) $20,(7)$.25 ; 
the suture between 3 and 4 is not very distinct. Legs with femur + trochanter 90 ; tibia $5 \mathrm{I}$; tarsus 50 , or rather more.

Hab.-Mendoza, Argentine Republic, Jan. 26, 1 \&98, on pithy stems of some herbaceous plant. This agrees with Hempel's $C$. novcesi in the small legs, with the tibia and tarsus about equal ; it also agrees externally, except that the wax of novcesi is paler and not so red. It seems best to regard the two as geographical races of one species.

(8.) Ceroplastes Bernardensis, n. sp.-Waxy scale about $61 / 2 \mathrm{~mm}$. long, 6 broad, and 5 I/2 high, creamy white, not divided into plates nor marked with white lines; dorsal nucleus white, with no dark area surrounding it. Denuded $q$ lively ferruginous, blackish dorsally ; length $4^{2} / 3$, breadth 3 , height $2 \frac{1}{2} \mathrm{~mm}$.; dorsum with a longitudinal crest ; caudal horn short but large, directed backwards.

Anal area with a ferruginous chitinous patch, the edges of which are not well defined; anal plates shaped as in $C$. scutigera; skin with scattered minute perforations; mouth-parts small, abouc г $30 \mu$ diameter.

Femur + trochanter, I $35 \mu$; tibia 100 ; tarsus 66.

Antennæ about $240 \mu$ long, S-jointed; joints measuring: (I.)?, (2.) 42 , (3.) 33 , (4.) 33 , (5.) 39 , (6.) $18,(7) 18$, (8.) 30.

Hab.-San Bernardino, Paraguay, Sept. 23, 1897. On twigs of undetermined plant. This agrees externally with the species which Hempel regards as $C$. Janeirensis, but the structure appears to be different. I cannot reconcile Hempel's Janeirensis with Signoret's account of that species, and believe it is wrongly identified. The South American species of Ceroplastes are so numerous that it is next to impossible to identify them by such descriptions as were given by the older authors; fortunately, these descriptions are few, and the great majority are well described by Mr. Hempel.

C. Amazonicus resembles Bernardensis, but on close inspection it is seen that the wax is divided into plates, though the sutures are colourless.

\section{A CANADIAN ANOPLONYX.}

BY W. Hague harRington, F. R. S. C., OtTAWA.

Among Hymenoptera which I sent to Provancher in $188_{5}$ was a sawfly which he determined as Nematus malacus, Nort. As it did not correspond to the description of that species, it was set aside with some undetermined material. While rearranging my Nematidæ, I recently examined the insect to ascertain its generic position, and found that 


\section{$2 \mathrm{BHL}$ Biodiversity Heritage Library}

Cockerell, Theodore D. A. 1902. "New Coccidae from the Argentine Republic and Paraguay." The Canadian entomologist 34, 88-93.

https://doi.org/10.4039/Ent3488-4.

View This Item Online: https://www.biodiversitylibrary.org/item/18808

DOI: https://doi.org/10.4039/Ent3488-4

Permalink: https://www.biodiversitylibrary.org/partpdf/3614

\section{Holding Institution}

MBLWHOI Library

Sponsored by

MBLWHOI Library

\section{Copyright \& Reuse}

Copyright Status: NOT_IN_COPYRIGHT

This document was created from content at the Biodiversity Heritage Library, the world's largest open access digital library for biodiversity literature and archives. Visit BHL at https://www.biodiversitylibrary.org. 